\title{
IQTISHODUNA
}

Vol. 17 (1), 2021

P-ISSN: 1829-524X, E-ISSN: 2614-3437

\section{Analisis Faktor-Faktor yang Mempengaruhi Kualitas Laba dengan Kualitas Audit sebagai Variabel Intervening Perusahaan Sektor Konsumsi di BEI}

\author{
Titin Krisnawati* ${ }^{*}$, Agung Budi Sulistyono², Siti Maria \\ Wardayanti ${ }^{3}$ \\ 1,2,3, Universitas Jember, Indonesia
}

\author{
*Corresponding Author \\ E-mail: kris.na84@yahoo.com
}

\begin{abstract}
Companies that have good profit quality can describe good company conditions. And an independent public accountant will provide good value to the company. The purpose of this research is to examine the quality of profits affected by liquidity, profitability, leverage, corporate growth, and audit quality in consumer goods industry sector companies in IDX. This study uses explanatory research based on hypothesis testing. The data used by secondary data and samples was selected using purposive sampling methods of 24 companies, with criteria covering listing companies in IDX for a minimum of three years, not performing corporate actions such as acquisitions or mergers during the observation period, having no negative return and total equity. The analysis used is descriptive, path analysis, and hypothesis test. The results showed liquidity, profitability, leverage, and growth of companies influenced the quality of profits through quality audits.
\end{abstract}

Keywords: liquidity, profitability, leverage, company growth, audit quality, profit quality

\begin{abstract}
Abstrak: Perusahaan yang memiliki kualitas laba yang baik dapat menggambarkan kondisi perusahaan yang bagus. Dan akuntan publik yang independen akan memberikan nilai baik pada perusahaan. Tujuan penelitian ini untuk meneliti kualitas laba yang dipengaruhi oleh likuiditas, profitabilitas, leverage, pertumbuhan perusahaan, dan kualitas audit pada perusahaan sektor industri barang konsumsi di BEI. Penelitian ini menggunakan explanatory research berbasis pengujian hipotesis. Data yang digunakan data sekunder dan sampel dipilih menggunakan metode purposive sampling sebanyak 24 perusahaan, dengan kriteria meliputi perusahaan listing di BEI minimal tiga tahun, tidak melakukan corporate action seperti akuisisi atau merger selama periode pengamatan, tidak memiliki laba dan total ekuitas negatif. Analisis yang digunakan adalah
\end{abstract}


deskriptif, path analysis, dan uji hipotesis. Hasil penelitian menunjukkan likuiditas, profitabilitas, leverage, dan pertumbuhan perusahaan berpengaruh terhadap kualitas laba melalui kualitas audit.

Kata Kunci: likuiditas, profitabilitas, leverage, pertumbuhan perusahaan, kualitas audit, kualitas laba

\section{Cara mencitasi:}

Krisnawati, T., Sulistyono, A.B., Wardayanti, S.M. (2021). Analisis Faktor-Faktor yang Mempengaruhi Kualitas Laba dengan Kualitas Audit sebagai Variabel Intervening Perusahaan Sektor Konsumsi di BEI. Iqtishoduna, 17 (1), 31-48.

\section{Pendahuluan}

Laporan keuangan merupakan komponen informasi perusahaan yang dipublikasikan sebagai hasil dari kinerja manajemen dan untuk memberikan informasi investor tentang arus kas. Laba yang berkualitas merupakan laba yang disajikan sesuai dengan kondisi perusahaan yang sebenarnya tanpa ada intervensi dari pihak-pihak berkepentingan dalam penyampaian laporan keuangan (Taruno, 2013). Kualitas laba didalam laporan keuangan akan sangat berguna bagi pasar modal karena akan membuat investor melakukan pengukuran terhadap nilai suatu perusahaan sebagai dasar untuk melakukan investasi. Likuiditas berpengaruh terhadap kualitas laba disebabkan perusahaan mempunyai kemampuan dalam membayar hutang jangka pendeknya, berarti perusahaan memiliki kinerja keuangan yang baik dalam pemenuhan hutang lancar sehingga perusahaan tidak perlu melakukan praktek manipulasi laba (Nurhanifah \& Jaya, 2014). Ukuran rasio likuiditas salah satunya adalah current ratio yang menunjukkan kredibilitas perusahaan dalam membayar hutang.

Laba perusahaan adalah indikator kemampuan perusahaan memenuhi kewajiban bagi investor dimana elemen dalam penciptaan nilai perusahaan 
yang menunjukkan prospek perusahaan dimasa yang akan datang (Gaol, 2014). Cara untuk menilai profitabilitas suatu perusahaan adalah bermacammacam dan tergantung pada laba dan aktiva atau modal mana yang akan diperbandingkan satu dengan yang lainnya (Reyhan, 2014). Salah satu ukuran profitabilitas adalah Return On Asset (ROA) yang berfungsi untuk mengukur efektifitas perusahaan dalam menghasilkan laba dan memanfaatkan aktiva yang dimilikinya. Kualitas laba juga berkaitan dengan leverage perusahaan. Leverage merupakan rasio untuk mengukur seberapa besar perusahaan dibiayai dengan hutang. Tingkat leverage akan diukur dengan rasio hutang atau debt ratio (Keown et al., 2008). Kualitas laba juga dapat dilihat dari besar kecilnya kesempatan pertumbuhan suatu perusahaan. Pertumbuhan perusahaan(growth) menjelaskan prospek pertumbuhan laba perusahaan. Kualitas laba dalam perusahaan dapat dikatakan berkualitas dan itu tercermin dari semakin bertumbuhnya perusahaan mencapai tingkatan yang lebih tinggi bagi investor (Pitria, 2017). Selama ini kualitas audit kebanyakan dikaitkan dengan KAP yang ditugaskan melakukan audit. KAP dibagi menjadi KAP yang termasuk dalam big four dan non big four. Dalam KAP auditor bertugas untuk melakukan monitoring pekerjaan manajer dengan sarana yaitu laporan keuangan tahunan, memberikan opini atas laporan keuangan, dan mempertimbangan kelangsungan hidup perusahaan (going concern) (Rudyawan \& Badera, 2009).

Mayangsari (2007) mengenai hubungan auditor tenure terhadap kualitas laba menunjukkan hasil bahwa tenure mempunyai hubungan negatif dengan discretionary accruals. Penelitian Baridwan \& Hariani (2010) tentang insentif untuk memanipulasi laba sebagai syarat keefektifan audit yang berkualitas dalam mengurangi manipulasi laba, menemukan bahwa audit yang berkualitas lebih efektif dalam mengurangi manipulasi daripada yang kurang berkualitas hanya bila ada insentif untuk memanipulasi laba terlebih dahulu. Sedangkan Indriani \& Kusumaputra (2016) menemukan bahwa 
tenure berpengaruh terhadap kualitas audit dan menjadi intervening terhadap kualitas laba.

Berdasarkan uraian faktor-faktor yang mempengaruhi kualitas laba, penelitian ini dilakukan pada sektor industri barang konsumsi dimana sektor ini merupakan industri yang terdiri dari perusahaan yang menghasilkan produk berupa barang yang akan dihabiskan atau dikonsumsi oleh konsumennya. Perusahaan industri barang konsumsi memiliki saham yang aktif diperdagangkan di bursa saham sehingga harga sahamnya juga bergerak aktif. Pergerakan saham yang aktif dapat digunakan sebagai ukuran kondisi perusahaan dilihat dari faktor likuiditas, profitabilitas, leverage, pertumbuhan perusahaan, dan kualitas laba. Sehingga tujuan dari penelitian ini adalah (1) untuk menguji dan menganalisis likuiditas, kualitas audit, dan kualitas laba perusahaan sektor konsumsi di BEI; (2) untuk menguji dan menganalisis profitabilitas, kualitas audit dan kualitas laba perusahaan sektor konsumsi di BEI; dan (3) untuk menguji dan menganalisis leverage, kualitas audit terhadap kualitas laba perusahaan sektor konsumsi di BEI; (4) untuk menguji dan menganalisis pertumbuhan perusahaan, kualitas audit, terhadap kualitas laba perusahaan sektor konsumsi di BEI.

\section{Kajian Pustaka}

\section{Kualitas Laba}

Kualitas laba merupakan kualitas informasi laba yang tersedia untuk publik yang mampu menunjukkan sejauh mana laba dapat mempengaruhi pengambilan keputusan dan dapat digunakan investor untuk menilai perusahaan (Wulansari, 2014). Laba yang berkualitas adalah laba yang mencerminkan kinerja keuangan perusahaan yang sebenarnya (Irawati, 2012). Karakteristik laba yang berkualitas menurut Warianto \& Rusiti (2013) yaitu (a) mampu mencerminkan kinerja operasi perusahaan saat ini dengan akurat; (b) mampu memberikan indikator yang baik mengenai kinerja perusahaan di masa depan; dan (c) dapat menjadi ukuran yang baik 
untuk menilai kinerja perusahaan.

\section{Likuiditas}

Likuiditas adalah kemampuan perusahaan untuk memenuhi hutang jangka pendeknya dengan aset lancar yang dimiliki. Sutrisno (2013) menyatakan bahwa likuiditas adalah kemampuan perusahaan untuk membayar kewajiban-kewajibannya yang segera harus dipenuhi. Rasio likuiditas yang umum digunakan adalah current ratio yang merupakan perbandingan antara hutang lancar dibagi aktiva lancar (Fahlevi, 2016). Proksi likuiditas dalam penelitian ini adalah Current Ratio. Perusahaan dengan likuiditas tinggi akan memiliki risiko yang relatif kecil sehingga kreditur merasa yakin dalam memberikan pinjaman kepada perusahaan dan investor akan tertarik untuk menginvestasikan dananya ke perusahaan tersebut karena investor yakin bahwa perusahaan mampu bertahan (tidak dilikuidasi). Wulansari (2014) menjelaskan pada saat laba dipublikasikan pasar akan merespon positif laba tersebut.

\section{Profitabilitas}

Profitabilitas merupakan rasio untuk menilai kemampuan perusahaan dalam mencari keuntungan (Kasmir, 2013). Rasio ini memberikan ukuran tingkat efektivitas manajemen suatu perusahaan. Hal ini ditunjukkan oleh laba yang dihasilkan dari penjualan dan pendapatan investasi. Penggunaan rasio profitabilitas dapat dilakukan dengan menggunakan perbandingan antara berbagai komponen yang ada dilaporan keuangan, terutama laporan posisi keuangan dan laporan laba rugi. Rasio profitabilitas mengukur kemampuan perusahaan menghasilkan laba bersih berdasarkan tingkat aset yang tertentu (Pitria, 2017). Kemampuan perusahaan dalam menghasilkan laba diukur dengan menggunakan Rasio Return on Asset (ROA).

\section{Leverage}

Leverage merupakan kemampuan perusahaan untuk menggunakan aktiva atau dana yang mempunyai beban tetap (fixed cost assets or funds) untuk memperbesar tingkat penghasilan (return) bagi pemilik perusahaan 
(Kasmir, 2013). Rasio leverage adalah ukuran dari seberapa banyak aset perusahaan berpengaruh terhadap ekuitas. Perusahaan dengan rasio leverage yang tinggi berarti perusahaan menggunakan hutang dan kewajiban lainnya untuk membiayai asset dan berisiko lebih tinggi dibandingkan perusahaan dengan leverage yang lebih rendah (Paramita, 2012). Leverage diproxykan dengan DER (Debt Equity Ratio) dimana perhitungan leverage sederhana membandingkan total hutang yang dimiliki perusahaan dengan total ekuitas pemegang saham. DER sangat mempengaruhi pencapaian laba yang diperoleh perusahaan. Peningkatan hutang yang digunakan oleh perusahaan akan menurunkan besarnya konflik keagenan antara pemegang saham dengan manajer.

\section{Pertumbuhan Perusahaan}

Pertumbuhan merupakan rasio yang mengukur seberapa besar kemampuan perusahaan dalam mempertahankan posisinya di dalam industri dan perkembangan ekonomi secara umum (Fahmi, 2012). Rasio pertumbuhan dapat dilihat dari berbagai segi, yaitu sales (penjualan), earning after tax (EAT), laba per lembar saham, dividen perlembar saham, dan harga pasar perlembar saham. Untuk mengukur pertumbuhan perusahaan menggunakan proksi dari penjualan dengan membandingkan penjualan pada tahun $\mathrm{t}$ setelah dikurangi penjualan pada periode sebelumnya terhadap penjualan pada periode sebelumnya yaitu menggunakan data profit of period.

\section{Kualitas Audit}

Kualitas audit diproksikan dalam KAP Big 4. Untuk mengukur kualitas audit menggunakan ukuran Kantor Akuntan Publik (KAP) menggunakan variabel dummy yaitu, menggunakan nilai 1 untuk perusahaan yang diaudit oleh KAP Big 4 dan nilai 0 untuk yang diaudit Non Big 4. Berikut ini adalah nama KAP yang termasuk dalam jajaran KAP Big 4, (a) Purwantono, Suherman \& Surja yang berafiliasi dengan Ernst and Young International (E \& Y); (b) Tanudireja, Wibisana \& rekan berafiliasi dengan PriceWaterhouse Coopers (PWC); (c) Shidharta dan Widjaja berafiliasi dengan 
Klynveld Peat Marwick Goeldener (KPMG) International; dan (d) Osman, Bing, Satrio, dan rekan berafiliasi dengan Delloitte Touche and Tohmatsu.

\section{Pengembangan Hipotesis}

Hipotesis yang dinyatakan untuk mengetahui pengaruh likuiditas $\left(\mathrm{X}_{1}\right)$, profitabilitas $\left(\mathrm{X}_{2}\right)$, leverage $\left(\mathrm{X}_{3}\right)$, dan pertumbuhan perusahaan $\left(\mathrm{X}_{4}\right)$ terhadap kualitas laba $(\mathrm{Y})$ melalui kualitas audit $\left(\mathrm{X}_{5}\right)$ adalah sebagai berikut.

H1. Ada pengaruh langsung dan tidak langsung likuiditas terhadap kualitas laba melalui kualitas audit.

H2. Ada pengaruh langsung dan tidak langsung profitabilitas terhadap kualitas laba melalui kualitas audit.

H3. Ada pengaruh langsung dan tidak langsung leverage terhadap kualitas laba melalui kualitas audit.

H4. Ada pengaruh langsung dan tidak langsung pertumbuhan perusahaan terhadap kualitas laba melalui kualitas audit.

Berdasarkan pengembangan hipotesis yang diusulkan, maka kerangka konseptual penelitian dijelaskan pada Gambar 1.

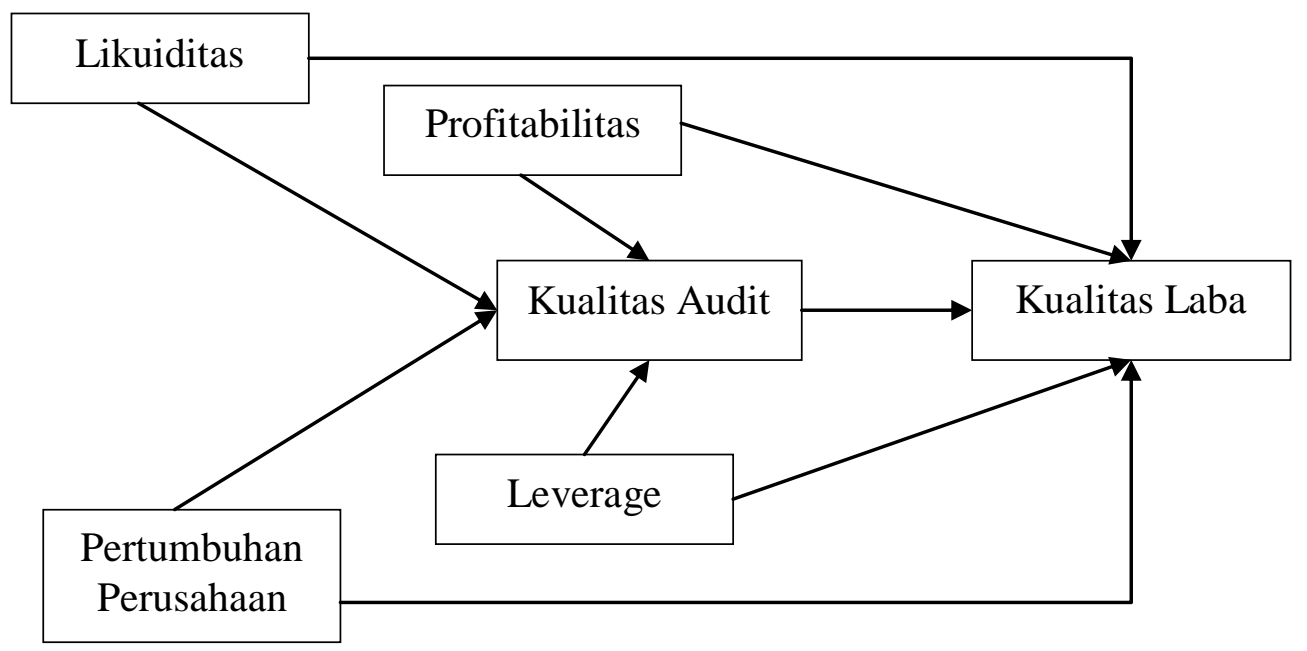

Gambar 1. Kerangka Konseptual Penelitian

IQTISHODUNA Vol. 17 (1), $2021 \mid 37$

http://ejournal.uin-malang.ac.id/index.php/ekonomi 
Titin Krisnawati, Agung Budi Sulistyono, Siti Maria Wardayanti

\section{Metodologi Penelitian}

Pendekatan dalam penelitian ini adalah explanatory research berbasis pengujian hipotesis yaitu penelitian yang ditujukan untuk menjelaskan hubungan kausal antara variabel-variabel penelitian dan menguji hipotesis yang dirumuskan (Sugiyono, 2013). Data yang digunakan adalah data sekunder berupa annual report perusahaan yang tercatat pada BEI tahun 2016-2018. Populasi dalam penelitian ini yaitu perusahaan sektor industri barang konsumsi sub sektor makanan \& minuman serta sub sektor farmasi. Sampel dipilih dengan metode purposive sampling, dengan kriteria (a) perusahaan listing di Bursa Efek Jakarta minimal tiga tahun; (b) perusahaan tidak melakukan corporate action seperti akuisisi atau merger selama periode pengamatan; dan (c) tidak memiliki laba dan total ekuitas negatif, karena saldo laba dan ekuitas yang negatif sebagai penyebut menjadi tidak bermakna. Teknik pengumpulan data dalam penelitian ini adalah dokumentasi dengan cara pengambilan data laporan keuangan tahunan.

Analisis data dalam penelitian ini meliputi statistika deskriptif, uji prasyarat, dan path analysis. Statistika deskriptif digunakan untuk mengetahui gambaran umum mengenai data penelitian dan hubungan yang ada antara variabel yang digunakan dalam penelitian. Uji prasyarat dalam penelitian ini meliputi (1) uji normalitas data untuk menguji apakah dalam sebuah model regresi, variabel independen, variabel dependen atau keduanya mempunyai distribusi normal ataukah tidak; (2) uji heterokedastisitas data untuk melihat apakah model memiliki varian residu yang sama; dan (3) uji multikolinieritas data untuk menguji apakah pada model regresi ditemukan adanya korelasi antar variabel independen. Dalam penelitian ini digunakan variabel bebas yaitu likuiditas $\left(\mathrm{X}_{1}\right)$, profitabilitas $\left(\mathrm{X}_{2}\right)$, leverage $\left(\mathrm{X}_{3}\right)$, dan pertumbuhan perusahaan $\left(\mathrm{X}_{4}\right)$; variable intervening yaitu kualitas audit $\left(\mathrm{X}_{5}\right)$; dan variabel terikat yaitu kualitas laba $(\mathrm{Y})$ Analisis jalur digunakan untuk mengetahui peran dari variabel intervening maka digunakan analisis jalur (path analysis) melalui dua langkah yaitu (1) melihat

38| IQTISHODUNA Vol. 17 (1), 2021

http://ejournal.uin-malang.ac.id/index.php/ekonomi 
koefisien path dengan pengaruh langsung; dan (2) melihat kombinasi antara pengaruh langsung dan tidak langsung (Solimun, 2002).

\section{Hasil dan Pembahasan}

\section{Analisis Deskriptif}

Dari analisis deskriptif yang dilakukan pada variabel likuiditas, profitabilitas, leverage, pertumbuhan perusahaan, kualitas audit, dan kualitas laba diperoleh hasil sebagai berikut.

Tabel 1. Hasil Analisis Deskriptif

\begin{tabular}{lcc}
\hline \multicolumn{1}{c}{ Variabel } & Nilai Minimum & Nilai Maksimum \\
\hline Likuiditas $\left(\mathrm{X}_{1}\right)$ &, 00 & 869,78 \\
Profitabilitas $\left(\mathrm{X}_{2}\right)$ & $-7,55$ & 52,67 \\
Leverage $\left(\mathrm{X}_{3}\right)$ &, 08 & 4,95 \\
Pertumbuhan Perusahaan $\left(\mathrm{X}_{4}\right)$ & $-6,28 \mathrm{E} 4$ & $5,27 \mathrm{E} 6$ \\
Kualitas Audit $\left(\mathrm{X}_{5}\right)$ & 0 & 1 \\
Kualitas Laba $(\mathrm{Y})$ & $-9,08 \mathrm{E} 6$ & $1,10 \mathrm{E} 6$ \\
\hline
\end{tabular}

Berdasarkan hasil analisis Tabel 1, secara umum perusahaan sub sektor makanan \& minuman serta sub sektor farmasi secara keseluruhan memiliki kemampuan likuiditas yang baik karena tidak ada perusahaan yang berada pada kondisi current ratio dengan nilai negatif. Dari sisi profitabilitas ada perusahaan yang berada dalam kondisi mengalami kerugian yang ditunjukkan dengan nilai profitabilitasnya negatif, ada perusahaan yang memperoleh peningkatan keuntungan yang ditunjukkan dengan nilai probabilitasnya positif. Secara leverage semua perusahaan dalam kondisi baik dan memiliki kemampuan menyediakan jaminan untuk para krediturnya. Pertumbuhan perusahaan sektor industri barang konsumsi ada yang mengalami pertumbuhan dan ada perusahaan yang mengalami penurunan pertumbuhan perusahaan. Untuk kualitas audit mereka sebagian diaudit oleh KAP Big 4 dan sebagian NonKAP Big 4. Terkait dengan kualitas laba tidak semua perusahaan berada pada kualitas laba yang baik. 


\section{Uji Prasyarat}

Uji normalitas data yang didasarkan pada uji grafik normal probability plot dalam penelitian ini menunjukkan bahwa data keenam variabel dalam penelitian ini berdistribusi normal. Hasil uji heteroskesdatisitas menggunakan scatterplot menunjukkan tidak terjadi heteroskesdatisitas dalam penelitian ini, sehingga layak digunakan untuk memprediksi kualitas laba berdasarkan masukan dari variabel likuiditas, profitabilitas, leverage, pertumbuhan perusahaan, dan kualitas audit. Dan secara uji multikolinieritas berdasarkan nilai VIF (Variance Inflation Factor) kurang dari 4, sehingga dapat disimpulkan tidak terjadi multikolinieritas.

\section{Uji Hipotesis}

Uji analisis regresi digunakan untuk mengetahui pengaruh signifikansi variabel bebas terhadap variabel terikat disajikan dalam Tabel 2.

\section{Tabel 2. Hasil Uji Analisis Regresi}

\begin{tabular}{|c|c|c|c|c|c|c|}
\hline Variabel & B & Std. Error & SC. Beta & t hitung & Sig. & Ket \\
\hline $\mathrm{X}_{1} \rightarrow \mathrm{X}_{5}$ & ,001 & ,000 & 308 & 2,761 & ,007 & Signifikan \\
\hline$X_{2} \rightarrow X_{5}$ & 016 & ,005 & 329 & 3,139 & 003 & Signifikan \\
\hline $\mathrm{X}_{3} \rightarrow \mathrm{X}_{5}$ & ,082 & ,065 & 132 & 1,260 & ,012 & Signifikan \\
\hline $\mathrm{X}_{4} \rightarrow \mathrm{X}_{5}$ & $1,442 \mathrm{E}-7$ & ,000 & ,341 & 3,473 & ,001 & Signifikan \\
\hline $\mathrm{X}_{1} \rightarrow \mathrm{Y}$ & $-796,311$ & 657,750 &,- 083 & $-1,211$ & ,030 & Signifikan \\
\hline $\mathrm{X}_{2} \rightarrow \mathrm{Y}$ & 56566,943 & 12388,594 & 299 & 4,566 & ,000 & Signifikan \\
\hline$X_{3} \rightarrow Y$ & $-15345,772$ & 145993,843 &,- 007 &,- 105 & ,017 & Signifikan \\
\hline $\mathrm{X}_{4} \rightarrow \mathrm{Y}$ & $-1,468$ & ,098 &,- 918 & $-14,939$ & ,000 & Signifikan \\
\hline $\mathrm{X}_{5} \rightarrow \mathrm{Y}$ & 26604,186 & 260223,586 &, 007 & ,102 & ,019 & Signifikan \\
\hline \multicolumn{2}{|c|}{ Constanta $\left(\mathrm{X}_{5}\right): 0,002$} & \multicolumn{2}{|c|}{ Fhitung : 11,544} & \multicolumn{3}{|c|}{ Constanta (Y) : -100439,148 } \\
\hline $\mathrm{R}$ & : 0,639 & \multirow{2}{*}{\multicolumn{2}{|c|}{ Sig F $\quad: 0,000$}} & $\mathrm{R}$ & $: 0,894$ & \multirow{2}{*}{$\begin{array}{l}\text { Fhitung : } 52,388 \\
\text { Sig F : } 0,000\end{array}$} \\
\hline $\mathrm{R}^{2}$ & $: 0,408$ & & & $\mathrm{R}^{2}$ & $: 0,799$ & \\
\hline
\end{tabular}

Hipotesis 1. likuiditas $\left(\mathrm{X}_{1}\right)$ berpengaruh terhadap kualitas laba (Y) melalui kualitas audit $\left(\mathrm{X}_{5}\right)$.

Hipotesis 2. Profitabilitas $\left(\mathrm{X}_{2}\right)$ berpengaruh terhadap kualitas laba (Y) melalui kualitas audit $\left(\mathrm{X}_{5}\right)$.

Hipotesis 3. Leverage $\left(\mathrm{X}_{3}\right)$ berpengaruh terhadap kualitas laba $(\mathrm{Y})$ melalui kualitas audit $\left(\mathrm{X}_{5}\right)$.

Hipotesis 4. Pertumbuhan Perusahaan $\left(\mathrm{X}_{4}\right)$ berpengaruh terhadap kualitas

40 | IQTISHODUNA Vol. 17 (1), 2021

http://ejournal.uin-malang.ac.id/index.php/ekonomi 
laba (Y) melalui kualitas audit $\left(\mathrm{X}_{5}\right)$.

\section{Uji Analisis Jalur}

Uji analisis jalur digunakan untuk mengetahui besarnya pengaruh variabel bebas yaitu likuiditas $\left(X_{1}\right)$, profitabilitas $\left(X_{2}\right)$, leverage $\left(X_{3}\right)$, pertumbuhan perusahaan $\left(\mathrm{X}_{4}\right)$ terhadap variabel terikat yaitu kualitas laba $(\mathrm{Y})$ melalui variabel intervening yaitu kualitas audit $\left(\mathrm{X}_{5}\right)$ perusahaan sektor industri barang konsumsi sub sektor makanan\& minuman serta sub sektor farmasi di Bursa Efek Indonesia.

Pertama, regresi untuk persamaan:

$\mathrm{X}_{5}=\mathrm{P}_{51} \mathrm{X}_{1}+\mathrm{P}_{52} \mathrm{X}_{2}+\mathrm{P}_{53} \mathrm{X}_{3}+\mathrm{P}_{54} \mathrm{X}_{4}+\mathrm{P}_{5 \varepsilon \mathrm{x}} \varepsilon_{\mathrm{X}}$; diperoleh model:

$\mathrm{X}_{5}=0,002+0,001 \mathrm{X}_{1}+0,016 \mathrm{X}_{2}+0,082 \mathrm{X}_{3}+1,442 \mathrm{X}_{4} ; \mathrm{R}^{2}=0,408$

atau

$\mathrm{ZX}_{2}=0,308 \mathrm{X}_{1}+0,329 \mathrm{X}_{2}+0,132 \mathrm{X}_{3}+0,341 \mathrm{X}_{4}$

Kedua, regresi untuk persamaan:

$\mathrm{Y}=\mathrm{P}_{\mathrm{y} 1} \mathrm{X}_{1}+\mathrm{P}_{\mathrm{y} 2} \mathrm{X}_{2}+\mathrm{P}_{\mathrm{y} 3} \mathrm{X}_{3}+\mathrm{P}_{\mathrm{y} 4} \mathrm{X}_{4}+\mathrm{P}_{\mathrm{y} 5} \mathrm{X}_{5}+\mathrm{P}_{\mathrm{y} \varepsilon y} \varepsilon_{\mathrm{y}} ;$ diperoleh model:

$Y=-100439.148-796.311 X_{1}+56566.943 X_{2}-15345.772 X_{3}-1.468 X_{4}+26604.186 X_{5} ; R^{2}=$ 0,799

atau

$Z Y=-0,083 X_{1}+0,299 X_{2}-0,007 X_{3}-0,918 X_{4}+0,007 X_{5}$

Berdasarkan model-model pengaruh tersebut dapat disusun model lintasan pengaruh sebagai berikut. Model lintasan ini disebut dengan analisis path, dimana pengaruh error ditentukan $\mathrm{P} \varepsilon_{\mathrm{i}}: \sqrt{1-R_{i}^{2}}$, maka $\mathrm{P} \varepsilon_{\mathrm{x}}=\sqrt{1-0,408}$ $=\sqrt{0,592}=0,769$ dan $\mathrm{P} \varepsilon_{\mathrm{y}}=\sqrt{1-0,799}=\sqrt{0,201}=0,448$. Untuk melihat seberapa jauh efek intervening masing-masing variabel intervening dalam konteks hubungan antara likuiditas, profitabilitas, leverage, pertumbuhan perusahaan, kualitas audit, dan kualitas laba, disajikan ke dalam diagram jalur pada Gambar 2. 
Titin Krisnawati, Agung Budi Sulistyono, Siti Maria Wardayanti

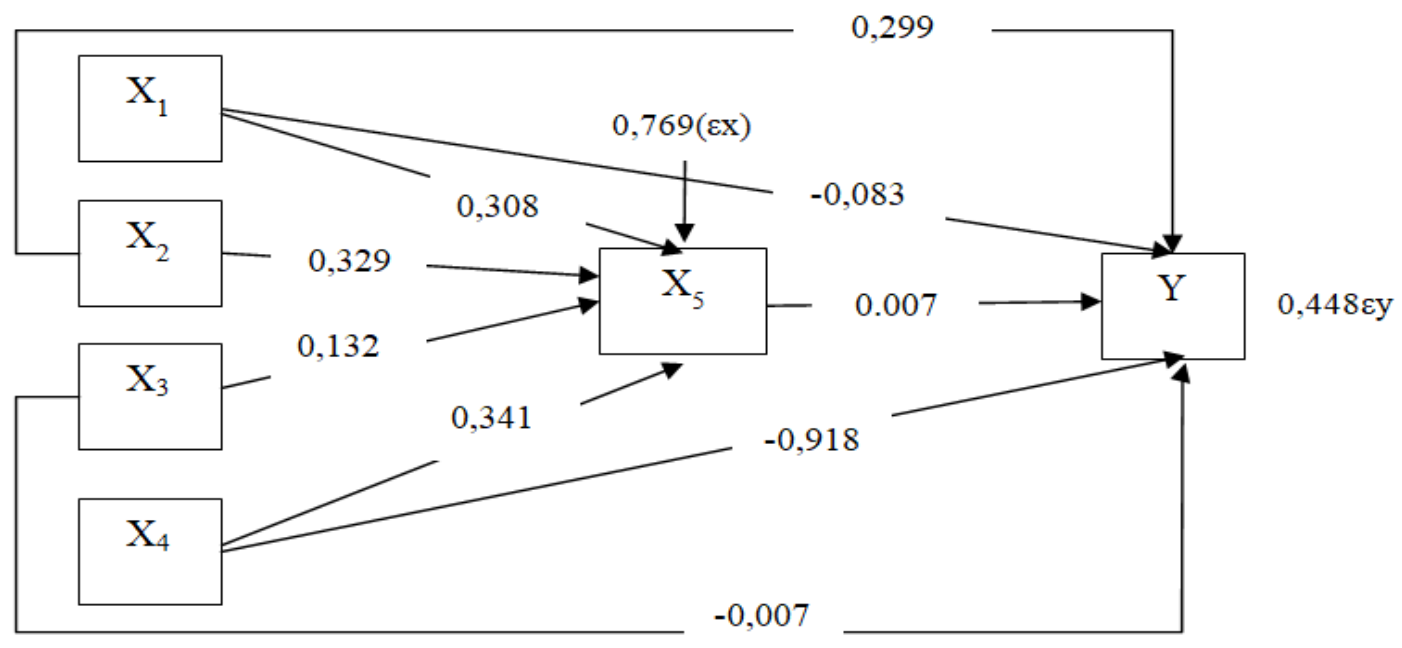

Gambar 2. Diagram Jalur Hubungan Kausal

Pengaruh langsung adalah pengaruh likuiditas, profitabilitas, leverage, dan pertumbuhan perusahaan terhadap kualitas laba dengan nilai koefisien regresinya. Efek intervening adalah indirect effect akibat introduksi variabel intervening diantara jalur (path) hubungan likuiditas, profitabilitas, leverage, pertumbuhan perusahaan, terhadap kualitas laba. Pada gambar 2 nampak besaran pengaruh pada jalur antara likuiditas, profitabilitas, leverage, dan pertumbuhan perusahaan terhadap kualitas laba melalui variabel intervening kualitas audit. Besarnya pengaruh langsung dan tidak langsung disajikan pada Tabel 3.

Tabel 3. Analisis Pengaruh Langsung dan Tidak Langsung

\begin{tabular}{ccrcc}
\hline Variabel & $\begin{array}{c}\text { Pengaruh } \\
\text { Langsung }\end{array}$ & $\begin{array}{c}\text { Tidak } \\
\text { Langsung }\end{array}$ & $\begin{array}{c}\text { Pengaruh } \\
\text { Total }\end{array}$ \\
\hline $\mathrm{X}_{1} \rightarrow \mathrm{Y}$ & &,- 083 & & \\
$\mathrm{X}_{1} \rightarrow \mathrm{X}_{5} \rightarrow \mathrm{Y}$ &, 308 &, 299 & 0,0022 & $-0,0808$ \\
$\mathrm{X}_{2} \rightarrow \mathrm{X}_{5} \rightarrow \mathrm{Y}$ &, 329 &,- 007 & 0,0023 & 0,3013 \\
$\mathrm{X}_{3} \rightarrow \mathrm{X}_{5} \rightarrow \mathrm{Y}$ &, 132 &,- 918 & 0,0009 & $-0,0061$ \\
$\mathrm{X}_{4} \rightarrow \mathrm{X}_{5} \rightarrow \mathrm{Y}$ &, 341 &, 007 & 0,0024 & $-0,9156$ \\
\hline
\end{tabular}

Dan uji kesesuaian model koefisien determinasi total penelitian ini yaitu:

$$
\begin{aligned}
R_{m}^{2} & =1-\left(1-R_{1}^{2}\right) \cdot\left(1-R_{2}^{2}\right) \\
& =1-(1-0,408) \cdot(1-0,799) \\
& =1-(0,592) \cdot(0,201) \\
& =1-0,119 \\
& =0,881
\end{aligned}
$$

42| IQTISHODUNA Vol. 17 (1), 2021

http://ejournal.uin-malang.ac.id/index.php/ekonomi 
Hasil perhitungan model koefisien determinasi total sebesar 0,881 menunjukkan bahwa korelasi atau hubungan antara kualitas laba dengan variabel independennya adalah kuat. Definisi "kuat" karena angka di atas 0,5. Hal ini berarti $88,1 \%$ variasi dari kualitas laba bisa dijelaskan oleh variasi dari variabel independen sedangkan sisanya 11,9\% dijelaskan oleh variabelvariabel di luar model penelitian ini. Pengaruh variabel bebas terhadap variabel terikat melalui variabel intervening dijabarkan sebagai berikut.

\section{Pengaruh Likuiditas Terhadap Kualitas Laba Melalui Kualitas Audit}

Likuiditas merupakan kemampuan perusahaan untuk membayar kewajiban-kewajibannya yang segera harus dipenuhi (Sutrisno, 2013). Rasio likuiditas yang umum digunakan adalah current ratio yang merupakan perbandingan antara hutang lancar dibagi aktiva lancar (Fahlevi, 2016). Sedangkan informasi likuiditas dan kualitas laba perusahaan yang terpubliksi harus sudah diaudit oleh KAP. Hasil penelitian menunjukkan bahwa pengaruh langsung variabel likuditas terhadap kualitas laba sebesar -8,3\% sedangkan pengaruh tidak langsung sebesar 0,22\%. Sehingga likuiditas berpengaruh terhadap kualitas laba melalui kualitas audit sebesar -8,08\%. Hasil penelitian ini sesuai dengan penelitian Susanti (2015) dengan hasil current ratio (CR) berpengaruh positif dan signifikan terhadap kualitas audit. Dan penelitian Moghaddam \& Abbaspour (2017) yang menyatakan likuiditas berpengaruh negatif terhadap kualitas laba.

\section{Pengaruh Profitabilitas Terhadap Kualitas Laba Melalui Kualitas Audit}

Efektifitas manajemen diukur dari rasio profitabilitas yang didasarkan pada pengembalian hasil yang didapatkan dari penjualan dan investasi. Perusahaan yang tingkat profitabilitas tinggi maka secara kualitas audit menunjukkan bahwa perusahaan tersebut mampu menjalankan usahanya dengan baik sehingga keberlangsungan hidup perusahaan dalam kondisi yang bagus. Kristiana (2012) menyatakan profitabilitas adalah kemampuan perusahaan memperoleh laba terkait dengan penjualan, total aset, maupun modal sendiri. Hasil penelitian menunjukkan bahwa pengaruh langsung 
variabel profitabilitas terhadap kualitas laba sebesar 22,9\% sedangkan pengaruh tidak langsung sebesar 0,23\%. Sehingga profitabilitas berpengaruh terhadap kualitas laba melalui kualitas audit sebesar 30,13\%. Hasil penelitian ini sesuai dengan penelitian Susanti (2015) yang menyatakan bahwa rasio profitabilitas yang diukur dengan ROE (Return On Equity) berpengaruh positif dan signifikan terhadap kualitas audit dan penelitian Praditasari \& Setiawan (2017) menyatakan bahwa profitabilitas berpengaruh terhadap kualitas laba.

\section{Pengaruh Leverage Terhadap Kualitas Laba Melalui Kualitas Audit}

Leverage merupakan ukuran yang dipakai dalam menganalisis laporan keuangan untuk memperlihatkan besarnya jaminan yang tersedia untuk kreditor, dan rasio leverage diukur dengan DER (Debt Equity Ratio). Gunawan \& Wahyuni (2013) menyatakan bahwa DER yang tinggi akan memperlihatkan nilai hutang yang besar, dengan hutang yang besar, dimana hutang itu dapat diijadikan modal untuk memutar kegiatan perusahaan untuk mendapatkan laba yang nantinya akan meningkatkan kualitas audit. Hasil penelitian menunjukkan bahwa pengaruh langsung variabel leverage terhadap kualitas laba sebesar $-0,7 \%$ sedangkan pengaruh tidak langsung sebesar 0,09\%. Sehingga leverage berpengaruh terhadap kualitas laba melalui kualitas audit sebesar -0,61\%. Hasil penelitian ini sesuai dengan penelitian Susanti (2015) yang menyatakan bahwa rasio leverage yang diukur dengan DER berpengaruh signifikan terhadap kualitas audit. Dan penelitian Moghaddam \& Abbaspour (2017) menemukan bahwa leverage berpengaruh terhadap kualitas laba.

\section{Pengaruh Pertumbuhan Perusahaan Terhadap Kualitas Laba Melalui Kualitas Audit}

Respon laba pada perusahaan yang memiliki pertumbuhan tinggi lebih besar dibanding dengan perusahaan yang memiliki pertumbuhan rendah. Peningkatan laba perusahaan akan direspon positif oleh pemodal. Dan baik buruknya kualitas audit pertumbuhan perusahaan dilihat dari rasio 
pertumbuhan penjualam perusahaan tersebut. Kim et al. (2003), menyatakan bahwa pertumbuhan penjualan dapat mempengaruhi kecenderungan perusahaan untuk mengelola laba. Hasil penelitian menunjukkan bahwa pengaruh langsung variabel pertumbuhan perusahaan terhadap kualitas laba sebesar $-91,8 \%$ sedangkan pengaruh tidak langsung sebesar $0,24 \%$. Sehingga pertumbuhan perusahaan berpengaruh terhadap kualitas laba melalui kualitas audit sebesar $-91,56 \%$. Hasil penelitian ini sesuai dengan penelitian Lee et al. (2006) yang menyatakan bahwa growth berpengaruh negatif terhadap kualitas laba dan Susanti (2015) yang menyimpulkan bahwa pertumbuhan perusahaan berpengaruh positif signifikan terhadap kualitas audit.

\section{Kesimpulan}

Likuiditas berpengaruh signifikan terhadap kualitas laba melalui kualitas audit; profitabilitas berpengaruh signifikan terhadap kualitas laba melalui kualitas audit; leverage berpengaruh signifikan terhadap kualitas laba melalui kualitas audit; dan pertumbuhan perusahaan berpengaruh signifikan terhadap kualitas laba melalui kualitas audit. Hasil penelitian ini diharapkan dapat memberikan manfaat bagi beberapa pihak yang berkepentingan antara lain bagi perusahaan, hasil penelitian dapat digunakan untuk meningkatkan kualita laba demi perkembangan perusahaan dimasa mendatang. Bagi investor (stakeholder), stakeholder tidak perlu merasa ragu untuk berinvestasi dan bergabung di perusahaan sektor industri barang konsumsi sub sektor makanan \& minuman, serta sub sektor farmasi. Bagi peneliti selanjutnya bisa mengembangkan penelitian melalui variabelvariabel lain yang belum diteliti dalam penelitian ini atau menganalisis dengan model analisis yang berbeda supaya dapat mengetahui pengaruhpengaruh lain yang mempengaruhi kualitas laba. 
Titin Krisnawati, Agung Budi Sulistyono, Siti Maria Wardayanti

\section{Daftar Pustaka}

Baridwan, Z., \& Hariani, A.R. (2010). Insentif Untuk Manipulasi Laba Sebagai Syarat Keefektifan Audit Yang Berkualitas Dalam Mengurangi Manipulasi Laba. Dapat diakses pada laman: http://www.ssrn.com

Fahlevi, R. (2016). Pengaruh Investmen Opprtunity Set (IOS), Voluntary Disclousere, Leverage dan Likuiditas terhadap Kualitas Laba (Studi Pada Perusahaan Manufaktu ryang Terdaftar di Bursa Efek Jakarta Periode 2010-2014). Tesis. Jakarta: FEB UIN Syarif Hidayatullah.

Fahmi, I. (2012). Analisis Laporan Keuangan. Cetakan ketiga. Bandung: Alfabeta.

Gaol, C. J. L. (2014). A to Z Human Capital Manajemen Sumber Daya Manusia. Jakarta: Grasindo Anggota IKAPI.

Gunawan, A., \& Wahyuni, S. F. (2013). Pengaruh Rasio Keuangan Terhadap Pertumbuhan Laba pada Perusahaan Perdagangan di Indonesia. Jurnal Manajemen dan Bisnis, 13(1), 63-84.

Indriani, R, \& Kusumaputra, A. D. (2016). Kualitas Laba: Implikasi dari Pengaruh Tenure Terhadap Kualitas Audit. Journal of Economic Management \& Business, 17(1), 61-73.

Irawati, D. E. (2012). Pengaruh Struktur Modal, Pertumbuhan Laba, Ukuran Perusahaan dan Likuiditas Terhadap Kualitas Laba. Accounting Analysis Journal, 1(2), 1-6.

Kasmir. (2013). Pengantar Manajemen Keuangan. Jakarta: Kencana.

Keown, Arthur et al. (2008). Dasar-dasar Manajemen Keuangan. Buku 1. Alih Bahasa Haryandini. Jakarta: Salemba Empat.

Kim, Y., Caixing, L., \& Rhee, S. G. (2003). The Effect of Size on Earning Management. Social Science Research Network Electronic Paper Collection. Diakses pada tanggal 1 Juli 2020 pada laman: http://paper.ssrn.com

Kristiana, I. (2012). Pengaruh Ukuran Perusahaan, Profitabilitas, Likuiditas, Pertumbuhan Perusahaan terhadap Opini Audit Going Concern pada Perusahaan Manufaktur yang Terdaftar di Bursa Efek Indonesis (BEI). Berkala Ilmiah Mahasiswa Akuntansi, 1(1), 47-51.

Lee, C., Li, L., Yue, H. (2006). Performance, Growth and Earnings Management. Review of Accounting Studies, 11(2), 305-334.

46| IQTISHODUNA Vol. 17 (1), 2021

http://ejournal.uin-malang.ac.id/index.php/ekonomi 
doi:10.1007/s11142-006-9009-9.

Mayangsari, S. (2007). The Auditor Tenure and the Quality of Earnings: Is Mandatory Auditor Rotation Useful?. Simposium Nasional Akuntansi X. Makasar.

Moghaddam, A., \& Abbaspour, N. (2017). The Effect of Leverage and Liquidity Ratios on Earnings Management and Capital of Banks Listed on the Tehran Stock Exchange. International Review of Management and Marketing, Econjournals, 7(4), 99-107.

Nurhanifah, Y.A., \& Jaya, T.E. (2014). Pengaruh Alokasi Pajak Antar Periode, Investment Opportunity Set dan Likuiditas terhadap Kualitas Laba. Jurnal Ilmiah Wahana Akuntansi, 9(2), 109-133.

Paramita, R.W.D. (2012). Pengaruh Leverage, Firm Size dan Voluntary Disclosure Terhadap Earning Response Coefficient (ERC). Jurnal WIGA, 2(2), 103-118.

Pitria, E. (2017). Pengaruh Kesempatan Bertumbuh, Leverage dan Profitabilitas Terhadap Kualitas Laba. Jurnal Akuntansi, 5 (1), 3-21.

Praditasari, N. A., \& Setiawan, P. E. (2017). Pengaruh Good Corporate Governance, Ukuran Perusahaan, Leverage, dan Profitabilitas Pada Tax Avoidance. E-jurnal Akuntansi Universitas Udayana, 19(2), 1229-1258.

Reyhan, A. \& Zirman., Nurazlina. (2014). Pengaruh Komite Audit, Asimetri Informasi, Ukuran Perusahaan, Pertumbuhan Laba Dan Profitabilitas Terhadap Kualitas Laba Studi Pada Perusahaan Manufaktur Yang Terdaftar Di BEI 2009- 2010. Jom Fekon 1(2), 1-17.

Rudyawan \& Badera. (2009). Opini Audit Going Concern: Kajian Berdasarkan Model Prediksi Kebangkrutan, Pertumbuhan Perusahaan, Laverage, dan Reputasi Auditor. Jurnal Ilmiah Akuntansi dan Bisnis, 4(2), 1-20.

Solimun. (2002). Structural Equation Modeling Lisrel \& Amos. Malang: Penerbit Universitas Negeri Malang.

Sugiyono. (2013). Metodelogi Penelitian Kuantitatif, Kualitatif dan $R \& D$. Bandung: Alfabeta.

Susanti, L. (2015). Financial Performance:Current Assets, Debt to Equity Ratio, Return on Asset and Growth towards Dividend Payout Ratio. International Conference on Management, Finance \& Enterpreunership (ICMFE), 4. 
Titin Krisnawati, Agung Budi Sulistyono, Siti Maria Wardayanti

Sutrisno. (2013). Manajemen Keuangan Teori, Konsep, dan Aplikasi. Yogyakarta: Ekonisia.

Taruno, S. A. (2013). Pengaruh Corporate Governance terhadap Kualitas Laba: Manajemen Laba sebagai Variabel Intervening. Accounting Analysis Journal 2(3), 323-329.

Warianto, P., dan Rusiti, C. H. (2013). Pengaruh Ukuran Perusahaan, Struktur Modal, Likuiditas dan Investment Opportunity Set (IOS) Terhadap Kualitas Laba Pada Perusahaan Manufaktur yang Terdaftar di BEI. Modus, 26(1), 19-32.

Wulansari. (2014). Pengaruh Ukuran Perusahaan, Kondisi Keuangan Perusahaan, dan Opini Audit Tahun Sebelumnya Terhadap Pemberian Opini Audit (Studi Pada Manufaktur Terdaftar di BEI). Skripsi. Universitas Muhamadiyah Malang. 